\title{
Fysiologie als metafoor
}

Citation for published version (APA):

van der Vusse, G. J. (2011). Fysiologie als metafoor: Afscheidsrede van Ger J. van der Vusse. (1 ed.) Universiteit Maastricht. https://doi.org/10.26481/spe.20110923gv

Document status and date:

Published: 23/09/2011

DOI:

10.26481/spe.20110923gv

Document Version:

Publisher's PDF, also known as Version of record

\section{Please check the document version of this publication:}

- A submitted manuscript is the version of the article upon submission and before peer-review. There can be important differences between the submitted version and the official published version of record.

People interested in the research are advised to contact the author for the final version of the publication, or visit the DOI to the publisher's website.

- The final author version and the galley proof are versions of the publication after peer review.

- The final published version features the final layout of the paper including the volume, issue and page numbers.

Link to publication

\footnotetext{
General rights rights.

- You may freely distribute the URL identifying the publication in the public portal. please follow below link for the End User Agreement:

www.umlib.nl/taverne-license

Take down policy

If you believe that this document breaches copyright please contact us at:

repository@maastrichtuniversity.nl

providing details and we will investigate your claim.
}

Copyright and moral rights for the publications made accessible in the public portal are retained by the authors and/or other copyright owners and it is a condition of accessing publications that users recognise and abide by the legal requirements associated with these

- Users may download and print one copy of any publication from the public portal for the purpose of private study or research.

- You may not further distribute the material or use it for any profit-making activity or commercial gain

If the publication is distributed under the terms of Article $25 \mathrm{fa}$ of the Dutch Copyright Act, indicated by the "Taverne" license above, 
Fysiologie als metafoor 



\section{Fysiologie als metafoor}

Rede uitgesproken ter gelegenheid van het bereiken van de pensioengerechtigde leeftijd door Ger J. van der Vusse,

Hoogleraar Fysiologie aan de voormalige Faculteit der Geneeskunde, nu Faculty of Health, Medicine and Life Sciences,

van de Universiteit Maastricht

Maastricht, 23 september 2011

Ger J.van der Vusse 
Fysiologie als metafoor 
Mijnheer de Rector, geachte collega's, beste familie en vrienden,

Het houden van een afscheidsrede impliceert dat de redenaar vervolgens de instelling verlaat en gaat genieten van zijn welverdiende rust. Ik kan $u$ gerust- of sommigen van $U$ wellicht teleur- stellen dat dit bij mij niet het geval is. Mijn afscheidsrede is geen reden voor afscheid. Aanstaande maandagochtend half negen begint ook voor mij, als onbezoldigd ambtenaar, weer een gewone werkdag. Waarom houd ik vandaag deze rede dan wel? In 1976 namen mijn werkzaamheden bij de capaciteitgroep Fysiologie van de toenmalige Medische Faculteit Maastricht, later Rijksuniversiteit Limburg, nu Maastricht University hun aanvang. Ik vond dit gegeven, mede gelet op het feit dat ik begin van dit jaar de pensioengerechtigde leeftijd heb bereikt, een goede gelegenheid om terug te kijken op 35 jaar academische arbeid in, op Amsterdam na, de mooiste stad van Nederland. Zoals elke universiteit in Nederland werd ook de nieuw opgerichte universiteit in Maastricht geacht actief te zijn op drie gebieden: onderzoek, onderwijs en maatschappelijke dienstverlening. Met name deze drie elementen wil ik in mijn rede de revue laten passeren en ingaan op de speciale plaats die de Fysiologie, een discipline die in de ruimste zin van het woord omschreven kan worden als de leer van het functioneren van onze organen en hun onderlinge samenhang, daarbij inneemt.

\section{Onderzoek}

Het eerste deel van mijn rede zal ik trachten zo persoonlijk mogelijk te houden en een korte samenvatting te geven van waar ik, samen met een groot aantal promovendi, post-docs en senior-onderzoekers, in de afgelopen jaren een deel van mijn tijd aan heb besteed. Hierbij zal ik mij beperken tot slechts twee onderzoekslijnen. De eerste heeft betrekking op de betekenis van vetzuren voor het functioneren (en dysfunctioneren) van de hartspier. Vetzuren zijn nuttig voor het hart, maar blijken onder bepaalde omstandigheden ook schadelijk te zijn. Het tweede onderwerp heeft betrekking op het calcium ion $\left(\mathrm{Ca}^{2+}\right)$ waar hetzelfde over gezegd kan worden. Het is een tweesnijdend zwaard: enerzijds essentieel en anderzijds een potentiële bedreiging voor een adequaat functioneren van het hart.

Toen ik in 1976 in Maastricht aan mijn onderzoek aan de hartspier begon, waren de richtlijnen, die ik mee kreeg van Rob Reneman, de eerste voorzitter van de capaciteitsgroep Fysiologie, zeer ruim. Het grote kader lag evenwel 
vast. Omdat het onderzoek van de capaciteitsgroep Fysiologie onderdeel uitmaakte van het Instituut Hart- en Vaatziekten, werd "Hartfunctie" het hoofdthema. Tijdens onze eerste brainstormsessies werden wij het eens over een onderzoekslijn waarin de rol, die vetzuren spelen in het normale en pathofysiologische functioneren van het hart, nader bestudeerd zou worden. Ruimer kon de omschrijving niet zijn, hetgeen mij in staat stelde een eigen invulling aan deze onderzoeksvraagstelling te geven en mij voornamelijk door nieuwsgierigheid te laten leiden. Het gehele project kon op een half A4'tje worden uitgeschreven, waarin de woorden "milestones" en "deliveries" niet voorkwamen.

Om meer begrip te kweken voor dit onderwerp wil ik beginnen met de behandeling van de volgende vragen: Wat zijn vetzuren en waarom zijn zij van belang voor de hartspier?

De functie van het hart is het rondpompen van bloed in het lichaam: zuurstofarm bloed naar de longen en zuurstofrijk bloed naar de organen, inclusief de hartspier zelf, die behoefte hebben aan zuurstof en voedingsstoffen om in hun energiebehoefte te voorzien. De hartspier trekt samen en ontspant, bij een mensenhart gebeurt dit ongeveer 1x per seconde, 6 ox per minuut, een leven lang. Voor het samentrekken en ontspannen van de hartspier is een continue aanvoer van zuurstof en voedingsstoffen nodig; stagneert deze aanvoer in de hartspier, bijvoorbeeld door een afgesloten bloedvat, dan resulteert dit uiteindelijk in een hartinfarct: een deel van het hartspierweefsel sterft af, draagt niet meer bij aan de pompfunctie of geeft aanleiding tot ritmestoornissen waardoor de pompfunctie van het gehele hart acuut stil kan komen te liggen. Een belangrijke groep voedingsstoffen voor de hartspier zijn langketenige vetzuren.

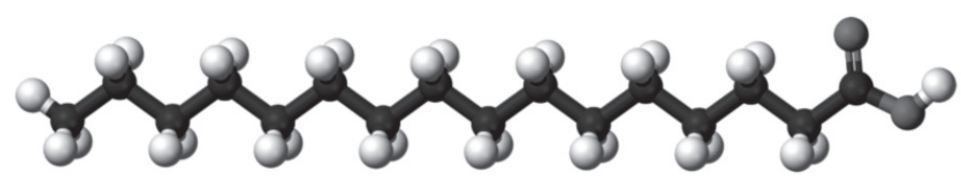

Figuur 1. Structuurformule van het langketenige vetzuur palmitinezuur

Vetzuren zijn chemische verbindingen die opgebouwd zijn uit een keten van tenminste 12 koolstofatomen met daaraan gekoppeld waterstofatomen, aan het einde bevindt zich een zuurgroep bestaande uit twee zuurstofatomen. In figuur 1 is palmitinezuur weergegeven waarvan de keten uit 16 koolstofatomen bestaat. Palmitinezuur komt in ruime 
mate voor in voedingsmiddelen zoals roomboter maar ook in ons eigen vetweefsel. De zuurgroep is waterminnend, de koolstofketen watervrezend. De watervrezende eigenschap overheerst waardoor het vetzuur in zijn geheel zeer slecht in water oplosbaar is.

Vetzuren worden ondermeer in onze hartspiercellen verbrand met behulp van zuurstof en leveren naast water en kooldioxide ATP. Deze verbinding bevat veel energie die aangewend wordt voor het doen samentrekken en ontspannen van het hart. Onder normale omstandigheden wordt tenminste $60 \%$ van de energiebehoefte van de hartspier gedekt door de verbranding van vetzuren, wat het belang van vetzuren voor een goede hartfunctie benadrukt (1). Het overige percentage komt op conto van glucose- en melkzuurverbranding. Omdat vetzuren zeer slecht in water oplosbaar zijn, komen zij in vrije vorm nauwelijks in het lichaam voor. Het merendeel van de vetzuren is gebonden aan glycerol en vormt zo neutraal vet dat voornamelijk in vetcellen en dus in ons vetweefsel opgeslagen zit. Het lichaam van een volwassen persoon met een normaal postuur en gewicht herbergt 15 tot 20 kilo vet, genoeg om het lichaam voor vele maanden te voorzien in zijn energiebehoefte.

Omdat de hartspiercel zelf geen vetzuren synthetiseert en de voorraad vet in deze cel beperkt is, is de spiercel afhankelijk van de aanvoer van vetzuren van buiten af; deze aanvoer vindt plaats via het bloed. De vetzuren zijn afkomstig uit het vetweefsel nadat zij losgemaakt zijn uit hun binding aan glycerol. Het grote probleem van de slechte oplosbaarheid van vetzuren in water (en dus ook in bloed) heeft de natuur opgelost door het bloed te voorzien van een eiwit, albumine genaamd, waaraan vetzuren kunnen binden (2). Het albumine molecuul bezit tenminste drie plaatsen met een hoge affiniteit voor langketenige vetzuren. Op deze wijze wordt de oplosbaarheid van vetzuren in bloed meer dan 1000 maal verhoogd en transport van voldoende hoeveelheden vetzuren vanuit het vetweefsel naar de hartspier gegarandeerd.

Omdat albumine een groot molecuul is dat de bloedbaan zelf niet kan verlaten, worden wij nu met een boeiende wetenschappelijke vraag geconfronteerd: hoe is het hart in staat om vetzuren op een zeer efficiënte manier uit de bloedbaan op te nemen, terwijl deze vetzuren zeer sterk aan bloed albumine gebonden zijn? Deze vraag hebben wij ons in het begin van de tachtiger jaren gesteld. Tijdens mijn sabbatical leave in 1985-1986 heb ik, financieel ondersteund door een NATO beurs, aan dit probleem mogen werken bij Jim Bassingthwaighte die verbonden is aan het Center of Bioengineering van de University of Washington te Seattle. Met behulp 
van complexe experimenten is onderzocht over welke mechanismen de hartspier beschikt om vetzuren vrij te maken uit de binding aan albumine en hoe deze vetzuren vervolgens door een aantal potentiële barrières heen getransporteerd worden naar de mitochondriën in de hartspiercel. Omdat in deze mitochondriën de verbranding van vetzuren plaats vindt, worden zij beschouwd als de energiecentrales van de hartspier. Figuur 2 is een electronenmicroscopische (EM) weergave van een dun plakje hartspierweefsel waarin het kleinste bloedvat, capillair genaamd, van waaruit zuurstof en voedingsstoffen door de hartspiercellen worden opgenomen, duidelijk zichtbaar is. Tevens zijn de endotheelcellen, die de wand van het capillair vormen, de interstitiële ruimte tussen endotheel en hartspiercel en de hartspiercel met contractiele eiwitten en mitochondriën te onderscheiden.

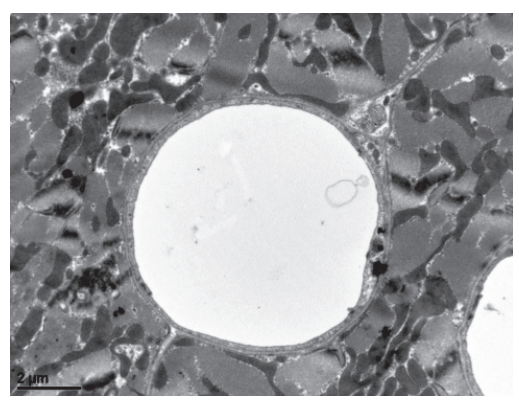

Figuur 2. EM foto van de hartspier

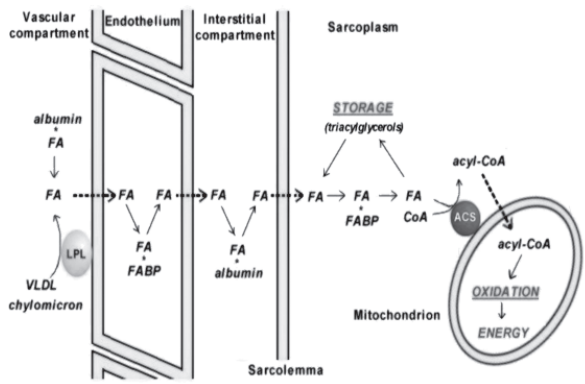

Figuur 3. Schematisch model FA transport

De afmetingen op deze foto zijn zeer klein; de diameter van het capillair bedraagt ongeveer 5 micrometer, terwijl de doorsnede van de endotheelcel niet meer dan een fractie van een micrometer is; afmetingen die met het blote oog niet zichtbaar zijn. Vanwege het feit dat vetzuren slecht in water oplosbaar zijn, vertegenwoordigen alle waterige ruimtes een potentiële barrière voor het transport van vetzuren vanuit het bloed naar de mitochondriën in de hartspiercel. Omdat celmembranen uit fosfolipiden bestaan, is het niet aannemelijk dat zij een ernstige barrière vormen in het vetzuurtransport. Om dit geheel te illustreren is, uitgaande van het electronenmicroscopische beeld, een schematisch model van de transportroute van vetzuur in het hart gemaakt (figuur 3).

Uit het onderzoek, dat in Seattle in de jaren 1985-1986 verricht is, zijn tot nu toe geen publicaties voortgekomen, niet omdat er toendertijd niet voortvarend gewerkt is, maar omdat onderzoek soms, net als het geval is bij goede wijn, de nodige rijping nodig heeft. In dit geval zelfs meer dan 25 
jaar; we mogen hier terecht spreken van een "grand cru". De voornaamste reden van deze enorme vertraging in het publiceren van deze gegevens lag in het simpele feit dat wij jarenlang niet in staat waren om op een relevante manier de grote hoeveelheid informatie te analyseren en te interpreteren. Hiervoor waren complexe computerprogramma's nodig die recht deden aan de micro-anatomie en chemische fysiologie van het hart, maar die tot voor kort niet voorhanden waren. Door de recente inbreng van mijn onvolprezen collega Theo Arts van de vakgroep Biofysica zijn wij sinds kort in staat om een serieus begin maken met het analyseren van de gegevens uit de jaren 80 en te komen tot een fysiologisch relevant antwoord op onze onderzoeksvraag. Zoals het er nu naar uitziet, zal de conclusie worden dat de belangrijkste barrière het vrijkomen is van de vetzuren uit de binding aan albumine in een dun laagje vloeistof vlak bij de endotheelcel in het bloedvat; het past allemaal net, het albumine-vetzuur complex verblijft net lang genoeg in het vloeistoflaagje, de zeer lage concentratie van vetzuren in het vloeistoflaagje is net hoog genoeg om voldoende vetzuren weg te laten diffunderen vanuit het bloed naar de endotheelcel en de overige potentiële barrières blijken geen wezenlijke belemmering op te leveren voor het transport van vetzuren naar het mitochondrion in de hartspiercel. Wel dient aangetekend worden dat de natuur hierbij voor een aantal elegante oplossingen heeft gezorgd. Ook in het interstitium, de ruimte tussen de cellen, bevindt zich albumine, waardoor vetzuren deze ruimte gemakkelijk kunnen passeren. In de hartspiercel zelf bevinden zich eiwitten, FABP genaamd, die, net als albumine in het bloed, vetzuren zeer sterk aan zich binden en op deze wijze zorgen voor gefaciliteerd vetzuurtransport binnen de cel. Over de betekenis van FABP voor het vetzuurtransport in het hart heb ik, na mijn terugkeer uit Seattle, samen met Jan Glatz uitgebreid onderzoek gedaan. Aangetoond kon worden dat FABP in de hartspiercel essentieel is voor een voldoende transportcapaciteit van het celmembraan naar de mitochondrion (3). Het mechanisme waarmee vetzuren door een celmembraan bewegen is nog steeds niet volledig opgehelderd; de wetenschappelijke meningen daarover lopen ver uiteen. Enerzijds denkt men bewijzen gevonden te hebben dat eiwitten in het celmembraan aanwezig zijn die vetzuren transporteren, anderzijds zijn er overtuigende experimentele resultaten gepubliceerd die aantonen dat vetzuren zonder enige hulp zeer snel door een biologische membraan diffunderen. Wat ook de uitkomst van verder onderzoek moge zijn, zeker is dat vetzuren een belangrijke energieleverancier zijn voor de hartspier. 
Naast het leveren van energie voor het rondpompen van bloed in het lichaam, zijn vetzuren nog om andere redenen van groot belang voor de hartspier. Vetzuren, variërend in ketenlengte van 16 tot 24 koolstofatomen, zijn in de vorm van fosfolipiden bouwstenen voor biologische membranen. De basisstructuur van een fosfolipide is een glycerol molecuul waaraan twee vetzuren en een alcoholgroep gekoppeld zijn. Deze fosfolipiden vormen een dubbellaag waarbij de vetminnende vetzuurstaarten zich in het binnenste van het membraan bevinden. De waterminnende groepen van het fosfolipidemolecuul vormen de buitenzijde van het membraan, grenzend aan het waterige celsap enerzijds en aan het bloed- of interstitiële compartiment anderzijds. Deze fosfolipide dubbellaag heeft de levensvormen mogelijk gemaakt zoals wij die nu op aarde kennen. Beschading van het celmembraan kan leiden tot celdood. Omdat het in stand houden van het celmembraan energie vergt, is de vraag gesteld of tijdens een afsluiting van een bloedvat in het hart, ten gevolge waarvan ischemie ontstaat en de energieproductie in de hartspier ernstig ontregeld raakt, afbraak van membraanfosfolipiden optreedt. Om deze vraag te beantwoorden is door Theo Roemen een nauwkeurige en betrouwbare analyse methode van vetzuren in weefsel ontwikkeld waarmee aangetoond kon worden dat in hartweefsel na 30 minuten ischemie vetzuren vrijkomen uit de celmembranen in een mate die goed overeenkomt met het verlies van eiwitten uit de hartspiercel; eiwitten die in de kliniek gebruikt worden als markers voor het aantonen van ischemische hartspierschade.

Een derde belangrijke rol die vetzuren spelen in de hartspier heeft betrekking op overdracht van informatie. Om met een nogal grof voorbeeld van informatieoverdracht te beginnen: bij toeval ontdekten wij in een onderzoekslijn, die geleid werd door Marc van Bilsen, dat vetzuren zeer toxisch kunnen zijn voor de hartspiercel. Wij waren op zoek naar een experimenteel model waarin met losse hartspiercellen de verbranding van vetzuren bestudeerd kon worden. Hiervoor kozen wij voor een model dat wereldwijd in veel laboratoria gebruikt wordt: hartspiercellen verkregen uit neonatale rattenharten en gecultiveerd in een kweekbakje. Dit model heeft tot voordeel dat meerdere variabelen tegelijkertijd in één experiment onderzocht kunnen worden en minder proefdieren nodig zijn.

Als deze hartspiercellen palmitinezuur te eten werd gegeven, stierven zij binnen 30 minuten af (4). We kregen zo een antwoord op een vraag die wij niet hadden gesteld; een typisch voorbeeld van serendipiteit. Nader onderzoek bracht aan het licht dat de hartspiercellen aangezet werden tot een proces dat geprogrammeerde celdood of apoptose genoemd 
wordt. Blijkbaar bevat palmitinezuur informatie die de cel als toxisch ervaart en uitlokt tot een reeks van opeenvolgende stappen die eindigt bij fragmentatie van de celkern en ineenschrompeling van de cel, waarna de cel overlijdt. Dit was een onverwacht en zelfs verbazingwekkend resultaat vooral als we ons realiseren dat in ons bloed palmitinezuur één van de meest voorkomende vetzuren is en door ons hart gretig wordt opgenomen om als energieleverancier te dienen. De vraag die zich nu opdringt is waarom hartspiercellen in ons lichaam niet afsterven, terwijl zij toch continu blootgesteld worden aan palmitinezuur, en waarom dit proces onder experimentele omstandigheden in een kweekbakje wel optreedt. De sleutel ligt in het gegeven dat het door ons ontworpen experiment reductionistisch van aard was en geen rekening hield met de fysiologische omstandigheden van het hart in ons lichaam.

Als ons bloed onderzocht wordt op de aanwezigheid van vetzuren dan blijkt dat palmitinezuur weliswaar een relatief veel voorkomend vetzuur is, maar zeker niet het enige vetzuur. Ook oliezuur is relatief ruim voorhanden. Als met deze kennis gewapend boven beschreven experiment herhaald wordt en de hartspiercellen blootgesteld worden aan een mengsel van palmitinezuur en oliezuur, dan stierven de cellen niet af en bleven daarentegen langdurig in leven. Dit resultaat verklaart waarom hartspiercellen in ons lichaam niet massaal afsterven omdat palmitinezuur niet als enige vetzuur in het bloed aanwezig is. Anderzijds leert het ons een nog belangrijkere les namelijk dat men bij het ontwerpen van een experiment niet de fysiologie uit het oog mag verliezen omdat een ongelukkig gekozen proefopzet tot misleidende resultaten kan leiden, hoe interessant de resultaten op zichzelf ook mogen zijn. Op een meer verfijnde schaal blijken vetzuren ook op een andere wijze informatie aan de hartspiercel over te dragen. Dit deel van het onderzoek, dat eveneens onder leiding van Marc van Bilsen is uitgevoerd, heeft een hoge vlucht kunnen nemen door de opkomst van de moleculaire biologie die zowel nieuwe meettechnieken als kennis heeft aangeleverd. Het hart wordt een omnivoor genoemd omdat het elke voedingsstof verbruikt die het aangeboden krijgt. Geeft men het hart suikers dan verbrandt het suikers om in zijn energiebehoefte te voorzien, hetzelfde geldt voor vetzuren. Hiermee is nog niet de vraag beantwoord waarom onder normale omstandigheden de hartspier liever vetzuren dan suikers als voedingsstof gebruikt en waarom het verbruik van vetzuren verder toeneemt als het hart langdurig blootgesteld wordt een een hoog vetzuurgehalte in het bloed. Het antwoord ligt in het gegeven dat de hartspiercel zowel waar kan nemen dat er vetzuren worden aangeboden alsook in welke hoeveelheid. Om vetzuren te verbranden zijn diverse transporteiwitten en enzymen 
nodig; de hartspiercel maakt deze eiwitten zelf en de code om deze eiwitten te synthetiseren ligt opgeslagen in het desbetreffende gen op het DNA. Het aflezen van deze code wordt gereguleerd door het promoterdeel van het gen. Deze promoter kan beschouwd worden als een slot dat het bijbehorende gen openzet of afsluit. Speciale eiwitten die aan het promoterdeel kunnen hechten fungeren als sleutel (Figuur 4). Een aparte groep van regulerende eiwitten zijn de PPARs, waar vetzuren (natuurlijke liganden) aan kunnen binden (5). Als deze binding een feit is, laat een eiwit, de co-repressor (Figuur 4A), los en wordt vervangen door een co-activator (Figuur 4B) en het gen gaat "van slot" af en de DNA code wordt vertaald in mRNA.

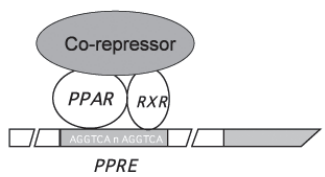

Figuur 4A. PPAR met co-repressor

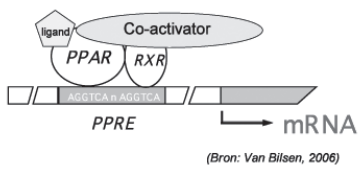

Figuur 4B. PPAR met ligand en co-activator

Vervolgens worden op basis van het mRNA eiwitten gesynthetiseerd die een rol spelen bij de energiehuishouding in de hartspier: de capaciteit om vetzuren te verbranden neemt toe en het vermogen om suikers te verbranden vermindert. Dit is bijzonder omdat men lange tijd heeft gedacht dat alleen primitieve levensvormen zoals bacteriën en schimmels tot dit type aanpassingen in staat waren, maar nu blijkt een gedifferentieerde cel zoals de hartspiercel ook over een dergelijk mechanisme te beschikken, hetgeen het belang van vetzuurverbranding voor de energiehuishouding van het hart extra benadrukt.

Dit geconcludeerd hebbende, dringt zich de vraag op wanneer in de evolutie vetzuurverbranding een belangrijke rol is gaan spelen. Lange tijd is de atmosfeer op aarde, waarvan het ontstaan ongeveer 4600 miljoen jaar geleden plaats vond, zuurstofloos geweest en kon er geen sprake zijn van vetzuurverbranding. De eerste eenvoudige levensvormen, de prokaryoten, verschenen omstreeks 3900 miljoen jaar geleden. Zij voorzagen zich op anaerobe wijze van energie. Nadat 3000 miljoen jaar geleden cyanobacteriën, die in staat waren moleculaire zuurstof te produceren, op aarde verschenen en het ijzer in de aardkorst uitgeroest was, steeg vanaf 2400 miljoen jaar geleden langzaam maar gestadig de 
zuurstofconcentratie in de atmosfeer. Omdat zuurstof toxisch is, vond toen één van de eerste grote ecologische rampen op aarde plaats (6). Tijdens deze zuurstofcatastrofe stierven massaal anaerobe levensvormen af, behalve die ééncelligen die een veilig heenkomen hadden gezocht in aardse krochten waarin zuurstof niet kon doordringen of die een systeem hadden weten te ontwikkelen om de schadelijke werking van zuurstof het hoofd te bieden. Eén van deze mechanismen is waarschijnlijk het verbranden van vetzuren geweest waardoor de cellulaire zuurstofconcentratie laag werd gehouden. Vetzuurverbranding was toen nog niet gekoppeld aan ATP productie, een proces dat pas vele miljoenen jaren later tot ontwikkeling is gekomen en mede de ontwikkeling van complexe levensvormen zoals wij die heden ten dage op aarde waarnemen mogelijk heeft gemaakt. In plaats van ATP synthese kwam toendertijd alle energie bij vetzuurverbranding vrij in de vorm van warmte. Een echo van deze primitieve vorm van vetzuuroxidatie wordt in ons lichaam nog steeds gehoord in het bruine vetweefsel. Recent onderzoek heeft aangetoond dat ook bij de volwassen mens vetzuurverbranding losgekoppeld van ATP productie in het bruine vetweefsel een essentiële rol speelt bij de warmtehuishouding in het lichaam (7).

Een tweede onderzoeksonderwerp waaraan ik de afgelopen jaren heb mogen werken betreft calcium, dat eveneens vetzuren een cruciale rol speelt in het functioneren van de hartspier. Financieel gesteund door een subsidie van de Europese Unie heb ik samen met Laci Ligeti, een helaas te vroeg overleden Hongaarse wetenschapper, aan de Semmelweis Universiteit in Budapest onderzoek gedaan naar de relatie tussen het calcium ion $\left(\mathrm{Ca}^{2+}\right)$ en hartfunctie. In de hartspiercel stijgt de $\mathrm{Ca}^{2+}$ concentratie om de spiercel te doen samentrekken, de concentratie daalt om de cel te doen ontspannen. Dit was al reeds vele jaren bekend; ook was bekend dat verstoringen in de cyclische veranderingen in de cellulaire $\mathrm{Ca}^{2+}$ concentratie aanleiding geven tot het optreden van bepaalde soorten hartziekten. Om dit proces nader te bestuderen is in Budapest een experimenteel model ontwikkeld waarmee, middels geavanceerde optische technieken, veranderingen in de $\mathrm{Ca}^{2+}$ concentratie in het intacte, werkende hart zichtbaar werden gemaakt. Een resultaat van dit onderzoek staat weergegeven in figuur 5 . Duidelijk is te zien dat eerst de $\mathrm{Ca}^{2+}$ concentratie in de hartspiercel toeneemt en dat enkele milliseconden daarna de druk in de holte van het hart stijgt, hetgeen gevolgd wordt door het uitpompen van bloed dat zich in deze holte bevindt. De $\mathrm{Ca}^{2+}$ concentratie daalt vervolgens en het hart ontspant zich om nieuw bloed de gelegenheid te geven de holte van de hartspier binnen te stromen. 
Deze repeterende patronen van veranderingen in de $\mathrm{Ca}^{2+}$ concentratie maakte het mogelijk om met behulp van computermodellen, ontwikkeld door Natal van Riel van de Technische Universiteit Eindhoven, dieper in de hartspiercel te kijken zonder deze cel te hoeven isoleren en uit elkaar te halen om de samenstellende delen apart te bestuderen. Deze benadering kan men een voorbeeld van "systems biology" noemen.

Ik zal niet ingaan op de wijze waarop de cel in staat is cyclisch de cellulaire concentratie van $\mathrm{Ca}^{2+}$ te veranderen. Wel op een aspect dat dit proces zo bijzonder maakt.

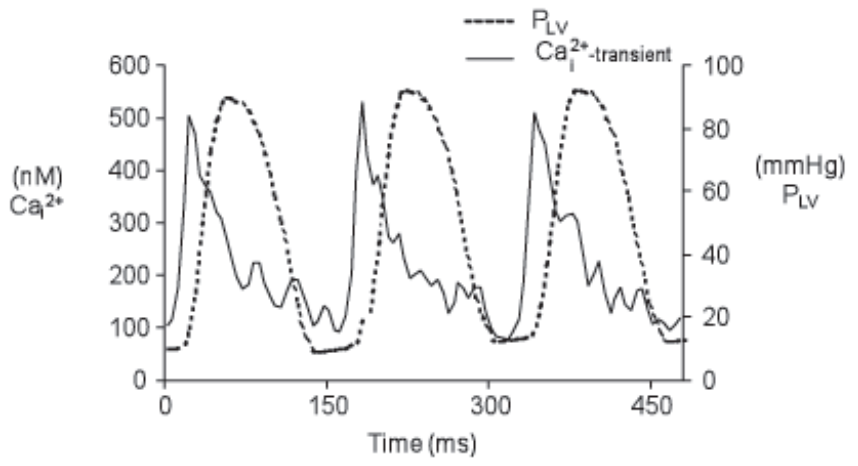

Figuur 5. Cyclische verandering in $\mathrm{Ca}^{2+}$ concentratie in hartspierweefsel en bloeddruk in de holte van het linker ventrikel (8).

Uit de gegevens in Figuur 5 kan berekend worden dat de $\mathrm{Ca}^{2+}$ concentratie in de hartspiercel varieert van ongeveer 100 tot 500 nanomol per liter celsap. Dit getal zegt op zich niet zoveel, wel als men zich realiseert dat de $\mathrm{Ca}^{2+}$ concentratie in het bloed, dus buiten de cel, maar wel in haar onmiddellijke nabijheid, ongeveer 2 millimol per liter is. Dit komt neer op een verschil van een factor 10.000 tussen buiten en binnen de cel. Evolutionair gezien is de optie om $\mathrm{Ca}^{2+}$ als regulator van de spiercontractie te laten fungeren blijkbaar een aantrekkelijke geweest, maar wel één met een enorme en continue bedreiging. Om een idee te vormen van wat een factor 10.000 betekent, dient $\mathrm{u}$ zich voor te stellen dat u ongeveer tot uw middel in een zwembadje gevuld met 1 meter water staat. Door middel van een miniscuul dunne wand wordt het water in uw badje gescheiden van een waterkolom van 10.000 meter hoog, de hoogte waarop moderne straalvliegtuigen zich door de lucht bewegen. Ik kan mij voorstellen dat u zich wat ongemakkelijk voelt. Toch zal de hartspiercel moeten leren leven 
met dit getalsmatige enorme concentratie verschil in $\mathrm{Ca}^{2+}$. Als het mis gaat, bijvoorbeeld als de celwand op een oncontroleerbare wijze doorlaatbaar wordt voor $\mathrm{Ca}^{2+}$, dan zal de hartspiercel verkrampen en overlijden; dit is één van de mechanismen waardoor hartspierweefsel te gronde gaat tijdens een afsluiting van een bloedvat, leidend tot een hartinfarct. Waarom dit onder normale omstandigheden niet gebeurt, heeft de Fysiologie ons geleerd. Niet alleen in de wand, maar ook in het inwendige van de hartspiercel zijn eiwitten aanwezig die op zeer efficiënte wijze $\mathrm{Ca}^{2+}$ of naar buiten pompen of naar plaatsen binnen in de cel waar zij veilig wordt opgeborgen. Het wegpompen van $\mathrm{Ca}^{2+}$ vergt veel energie. Als de energievoorziening evenwel geleidelijk aan tekort schiet, dan zal de $\mathrm{Ca}^{2+}$ concentratie gedurende de ontspanningsfase (diastole) niet genoeg dalen en wordt verhinderd dat voldoende vers bloed de holte van de hartspier instroomt. In de kliniek wordt dit diastolisch hartfalen genoemd, een veel voorkomende aandoening bij de oudere patiënt.

Het enorme verschil tussen $\mathrm{Ca}^{2+}$ concentratie buiten en de binnen de hartspiercel is niet de enige dreiging die uitgaat van het calcium ion. Ik doel nu op een pathologisch proces dat atherosclerose of aderverkalking genoemd wordt: het neerslaan van kalkzouten in de vaatwand, ondermeer in de wand van bloedvaten die het hart zelf van zuurstofrijk bloed dienen te voorzien. Voordat ik inga op mijn eigen bijdrage aan het onderzoek naar de mogelijke oorzaak van atherosclerose wil ik graag een passage uit de Bijbel, Genesis 19 vers 26, citeren (9). Voor diegenen die nog minder bijbelvast zijn dan ik: deze passage heeft betrekking op de vernietiging van Sodom en Gomorra en de miraculeuze redding van Lot en zijn twee dochters. Zijn vrouw overleeft het door de HEER aangerichte inferno evenwel niet. De tekst luidt:

Toen liet de HEER uit de hemel zwavel en vuur neerkomen op Sodom en Gomorra en HIJ vernietigde die steden en de hele vallei, met de inwoners van al die steden en met alles wat er op het land groeide. De vrouw van Lot, die achter hem liep, keek om en veranderde in een zoutpilaar.

Ik wil mij hier niet laten verleiden tot een theologische beschouwing over deze Bijbeltekst omdat ik mij daar als atheïst niet toe gerechtigd acht. Ook zal ik niet nader in gaan op de vraag waarom de HEER een vrouw bestraft met de dood, nadat zij uit nieuwsgierigheid omkijkt om te aanschouwen wat de HERE heeft aangericht. Nieuwsgierigheid was en is altijd een belangrijke drijfveer geweest voor wetenschappelijk onderzoek, wellicht is de HEER niet 
gesteld op wetenschappelijke onderzoekers. Wel wil ik te berde brengen wat de wetenschap nu, met de enorme vlucht die zij de afgelopen eeuw heeft doorgemaakt, als alternatieve, wellicht troostrijke verklaring kan aanreiken voor bovenstaand Bijbelcitaat. De aardwetenschap heeft ons uitgebreide kennis verschaft over tectonische platen in de aardkorst. Het langs elkaar schuiven ervan geeft aanleiding tot aardbevingen en vulkanische activiteit. Bij een vulkanische eruptie worden grote hoeveelheden gloeiendheet lava (vuur) en zwavel de atmosfeer ingeslingerd met een kracht en omvang die gehele steden van de aardbodem laten verdwijnen. Denkt $u$ maar aan Pompeï en Herculaneum bij de uitbarsting van de Vesuvius in 79 AD. Lastiger lijkt het om de verandering van de vrouw van Lot in een zoutpilaar te verklaren. Wat voor zout zou dit geweest kunnen zijn? Met de fysiologische en biochemische kennis van nu kan gesteld worden dat dit hoogstwaarschijnlijk calcium-fosfaat is, een zeer onoplosbaar calciumzout dat ondermeer een belangrijk bestanddeel is van ons skelet.

Dit brengt mij tot het tweede voorbeeld van een fysiologisch systeem dat in ons lichaam op het scherp van de snede balanceert. De concentratie van zowel calcium als fosfaat, een molecuul opgebouwd uit fosfor en vier zuurstofatomen, is in de orde van 2 millimol per liter bloedplasma en interstitiële vloeistof. Middelbare school scheikunde leert ons dat bij deze concentratie van calcium en fosfaat het oplosbaarheidsproduct, zijnde $2 \times 10^{-33}$, van het calciumfosfaat kristal $\mathrm{Ca}_{3}\left(\mathrm{PO}_{4}\right)_{2}$, vele malen wordt overschreden (10). Met andere woorden: in ons lichaam is het mengsel van $\mathrm{Ca}^{2+}$ en fosfaat super-gesatureerd; bij een geringe verstoring zal een neerslag van calciumfosfaat ontstaan. Als dit op grote schaal in het lichaam plaats vindt, zal zich uiteindelijk een zoutpilaar vormen. Dat dit op dit moment bij mij niet gebeurt, komt door een ingenieus systeem dat de vorming van calciumfosfaat in het lichaam tegengaat behalve daar waar het nodig is, dat wil zeggen in het skelet. Dit systeem bestaat uit een groot aantal eiwitten en andere factoren die ervoor zorgen dat calciumfosfaat niet ongecontroleerd kan neerslaan. Dit beschermende systeem werkt bijna perfect. Met nadruk op bijna omdat er wel degelijk omstandigheden zijn waarbij zoutvorming het op de lange duur gaat winnen van het in oplossing houden van calcium en fosfaat ionen. Eén van de plaatsen in het lichaam waar het mis kan gaan is de wand van onze bloedvaten. Deze pathologische aandoening noemt men atherosclerose, het verkalken van de wand van het bloedvat, waardoor uiteindelijk het vat volledig dicht gaat zitten en er geen bloed meer door heen stroomt.

De vraag die wij ons enige jaren terug gesteld hebben is wanneer de eerste tekenen van calciumfosfaat neerslag in de bloedvaten van het mensenhart 
te zien zijn: is dit een laat fenomeen of een proces dat al zeer vroeg in de tijd plaats vindt? Ik prijs mij gelukkig met het feit dat ik voor de beantwoording van deze vraag een partner vond in de persoon van Martien de Voigt, hoogleraar Kernfyica aan de TU Eindhoven. Zijn afdeling beschikt over een singletron, waarmee een stabiele protonenbundel met een diameter van ongeveer 1 micrometer (één duizendse van de dikte van een vingernagel) wordt gegenereerd. Als met deze bundel een dun plakje van een menselijk bloedvat wordt bestraald, kan de elementsamenstelling van de vaatwand bepaald worden.

De patholoog deelt de ernst van een atherosclerotische verandering van de vaatwand in 7 categorieën in. De hoogste categorie, aangeduid met het Romijnse cijfer VII, wordt gekaraktiseerd door een ernstige mate van verdikking van de vaatwand met daarin uitgebreide platen of schollen van calciumfosfaat kristallen. In de laagste categorie (stadium I) is met de klassieke pathologische onderzoeksmethoden slechts een matig verdikte binnenste laag van het bloedvat, de intima, zichtbaar zonder aanwijzingen voor calcificaties. In eerste instantie heeft ons onderzoek zich gericht om een middenstadium van atherosclerose (stadium IV). De intima vertoonde de karakteristieke verdikking en de protonenbundel liet gebieden zien met een verhoogde aanwezigheid van micro-calcificaties (Figuur 6). De calciumbevattende kristallen hadden een afmeting die veelal varieërde tussen de 1 en 10 micrometer (11).

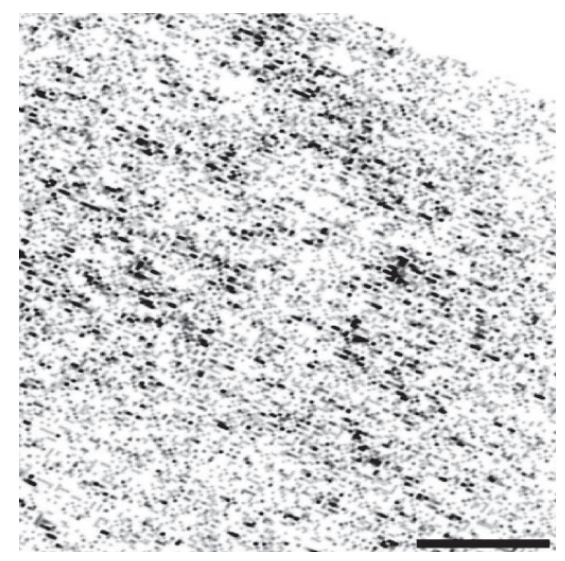

Figuur 6. Stadium IV met calcificaties 
Als nu een vat met stadium I onderzocht werd, troffen wij inderdaad een matig verdikte intima en geen spoor van microcalcificaties aan. Niet tevreden met dit resultaat werd de protonenbundel nog verder verkleind en de bestralingsduur verlengd, waardoor het oplossend vermogen en de gevoeligheid van de bepaling sterk toenamen. Bij minitieus aftasten van de vaatwand met een stadium I aandoening werden nu wel degelijk kleine calciumzout kristallen gevonden met een afmeting van minder dan 1 micrometer (11).

De conclusie die uit dit onderzoek getrokken mag worden is dat het neerslaan van onoplosbare calciumzouten al in een zeer vroegtijdig stadium in het atherosclerotisch proces optreedt. Nader onderzoek zal moeten uitwijzen of dit calciumneerslag de primaire oorzaak is van atherosclerose of slechts bijdraagt aan de verergering van dit pathofysiologisch, en uiteindelijk levensbedreigend, proces. Experimentele resultaten verkregen door andere onderzoeksgroepen doen evenwel het ergste vrezen. Aangetoond werd dat gladde spiercellen, die veelvuldig voorkomen in de verdikte intima, afsterven zodra zij blootgesteld worden aan microscopisch kleine calciumzout kristallen. Tijdens het afsterven komen structuren vrij waaraan calcium zich gemakkelijk hecht en zo als startpunt dienen voor de vorming van nieuwe calciumzout kristallen. Er treedt een vicieuze cirkel op. Daarnaast is aangetoond dat ontstekingscellen geactiveerd worden als zij geconfronteerd worden met calciumzout kristallen met een afmeting in de orde van sub-micrometers. Als dit proces ook verloopt in de vaatwand, kan men spreken van twee vicieuze cirkels omdat ontstekingscellen geacht worden een bijdrage te leveren aan het ontstaan en opgang houden van het atherosclerotisch proces (11).

Daar de protonenbundel naast calcium ook andere elementen zichtbaar maakt, stelde deze techniek ons in staat de aard van het calciumzout te onderzoeken. In alle gevallen troffen wij een exacte co-localisatie aan van het element calcium en fosfor, hetgeen duidt op calciumfosfaat neerslag. In tegenstelling tot hetgeen in de leerboeken vermeld staat, bleek het calciumfosfaat neerslag niet hydroxyapatiet te zijn, het zout waaruit ons botmateriaal is opgebouwd, maar eerder amorf calciumfosfaat met mogelijke bijmengingen van carbonat en uraat. Interessant is dat op dezelfde plaats waar calciumfosfaat werd aangetroffen ook een verhoogde concentratie van ijzer en zink werd waargenomen (11). Welke betekenis daar aan gegeven dient te worden, weten we momenteel niet. Verder onderzoek is nodig om deze vraag op te helderen. 


\section{Onderwijs}

Naast onderzoek, is onderwijs een gebied waar de universiteit geacht wordt zich te profileren. De Medische Faculteit Maastricht (MFM) heeft zich in deze niet onbetuigd gelaten door als eerste in Nederland het probleemgestuurd onderwijs (PGO) in het geneeskunde curriculum in volle omvang te omarmen. Van meet af aan ben ik een groot voorstander geweest van de uitgangspunten van het Maastrichtse onderwijssysteem. Toen in de jaren 1971-1975, tijdens mijn promotieonderzoek aan de Erasmus Universiteit Rotterdam, informatie begon door te sijpelen dat in Maastricht het onderwijs aan medische studenten op een totaal andere leest geschoeid zou worden en de contouren van het PGO systeem duidelijk werden, heb ik in 1974 een spontane sollicitatiebrief gestuurd naar de afdeling Personeelszaken van de MFM. Tot op heden heb ik nog geen reactie op deze brief mogen ontvangen; waarschijnlijk is mijn brief zoek geraakt of per ongeluk in de versnipperaar terecht gekomen. .

Zelf ben ik tijdens mijn studie Scheikunde onderworpen geweest aan het klassieke onderwijssysteem: 's-ochtends colleges en 's-middags practica. Aan het einde van het trimester enige weken vrij om mij op tentamens voor te bereiden, vervolgens weer een nieuw trimester met colleges en practica gevolgd door een serie tentamens. Informatieoverdracht vond voornamelijk plaats door middel van hoorcolleges, die, op enkele uitzonderingen na, weinig sprankelend waren, wat duidelijk bleek uit de tanende opkomst van studenten. Bij het eerste college zat de zaal stampvol (300 eerste jaars Scheikunde bij de Gemeente Universiteit Amsterdam, ik spreek nu over het jaar 1964), bij het tweede college was de helft over, bij het derde college nog maar twee rijen waarbij de eerste rij volledig gereserveerd was voor, of beter gezegd ingenomen werd door, King Kong. De wegblijvers studeerden uit collegedictaten geleend van anderen of uit aanbevolen studieboeken Al snel was het mij duidelijk dat collegeseries een goed bedoelde poging waren om kennis over te dragen maar minder geschikt om kennis te verwerven. Voor nadere informatie over King Kong kan verwezen worden naar een onderhoudend boek van Ben Haveman, getiteld: Oh, gelukkige eenzaamheid (12). In dit boek worden een aantal sociaal onaangepaste personen ten tonele gevoerd waarvan enkelen een veilige haven hadden gevonden binnen de muren van de universiteit, een situatie die heden ten dage ondenkbaar is.

Een tweede, meer anecdotisch voorval heeft mijn interesse in andere onderwijssystemen nog verder versterkt. Tijdens het college Statistische Thermodynamica verscheen de waterstofatoomvergelijking van 
Schrödinger op het bord. Tot dat moment dacht ik in mijn grenzelose naiviteit dat het waterstofatoom een relatief simpele structuur was, maar op die bewuste dag werd deze droom ruw verstoord.

$$
\begin{aligned}
\frac{-\hbar^{2}}{2 \mu} \frac{1}{r^{2} \sin \theta}\left[\sin \theta \frac{\partial}{\partial r}\left(r^{2} \frac{\partial \Psi}{\partial r}\right)+\right. & \left.\frac{\partial}{\partial \theta}\left(\sin \theta \frac{\partial \Psi}{\partial \theta}\right)+\frac{1}{\sin \theta} \frac{\partial^{2} \Psi}{\partial \phi^{2}}\right] \\
& +U(r) \Psi(r, \theta, \phi)=E \Psi(r, \theta, \phi)
\end{aligned}
$$

Figuur 7 . Schrödinger's waterstofatoom vergelijking

Het feit dat deze vergelijking nauwelijks werd toegelicht, maar wel geacht werd voor het tentamen gekend te zijn, heeft mij geleerd dat conceptueel inzicht veel belangrijker is dan het klakkeloos reproduceren van formules of theorieën. Een discussie tussen de docent en student en studenten onderling biedt de mogelijkheid om tot dit gewenste conceptuele inzicht te komen. Dit wil overigens niet zeggen dat het aanleren van feitenkennis overbodig is. Integendeel, zonder feitenkennis bestaat het risico dat men blijft steken in algemeenheden en oppervlakkige inzichten.

Het PGO systeem biedt de mogelijkheid om beide aspecten in zich te verenigen: feitenkennis verkrijgen op een intellectueel uitdagende wijze en deze te gebruiken voor het construeren van concepten en het adequaat oplossen van medisch-gerelateerde problemen. Het moet mij na 35 ervaringsjaren van het hart dat, ondanks deze mogelijkheden, het PGO onderwijs in het geneeskunde curriculum de mooie beloften slechts in beperkte mate waar heeft kunnen maken. Bij mijn weten is geen bewijs voorhanden dat in Maastricht opgeleide basisartsen aanzienlijk betere artsen zijn en over meer kennis beschikken dan collega's die onderworpen zijn geweest aan een klassiek onderwijssysteem. De constatering, dat de Maastrichtse basisartsen ook niet minder zijn, is een schrale troost.

Voordat ik inga op een aantal weeffouten in het Maastrichtse PGOgeneeskunde curriculum, die mijns inziens in belangrijke mate hebben bijgedragen aan het gegeven dat onze studenten niet met kop en schouders uitsteken boven studenten van elders, zal ik eerst, voor diegenen die niet bekend zijn met het geneeskunde curriculum, kort uitleggen hoe het is opgebouwd. Het curriculum duurt nominaal 6 jaar: in de eerste twee jaren vindt voornamelijk theoretische scholing plaats in kleinschalige onderwijsgroepen bestaande uit 8 tot 10 studenten. Het jaar is verdeeld in 6 blokken, die thematisch samengesteld zijn. Het onderwijs wordt aan de hand van papieren casuistiek geïntegreerd aangeboden. Daartoe leveren, afhankelijk van het onderwerp van het blok, diverse vakgebieden een bijdrage. 
Naast onderwijsgroepen die twee keer per week 2 uur bijeenkomen in de aanwezigheid van een tutor worden enkele lezingen verzorgd over onderwerpen die betrekking hebben op het thema van het blok.

Praktisch onderwijs wordt aangeboden in het Skillslab en betreft voornamelijk het aanleren van medische onderzoekstechnieken, veelal op studenten zelfen op simulatie-patiënten. In jaar drie krijgen de studenten de gelegenheid om met echte patiënten in contact te komen op de zogenaamde studentpoli's. Daarnaast zijn er nog onderwijs-groepsbijeenkomsten en enkele kleinschalige lezingen. Jaar 4 en 5 is gereserveerd voor co-schappen; de studenten lopen stage ondermeer bij ziekenhuisafdelingen, in huisartspraktijken en verpleeghuizen. In het $6^{\mathrm{e}}$ jaar wordt het GEZP en WESP programma aangeboden, langdurige wetenschaps- en klinische stages, die door mijn collega Luc Snoeckx op uitstekende wijze vorm zijn gegeven.

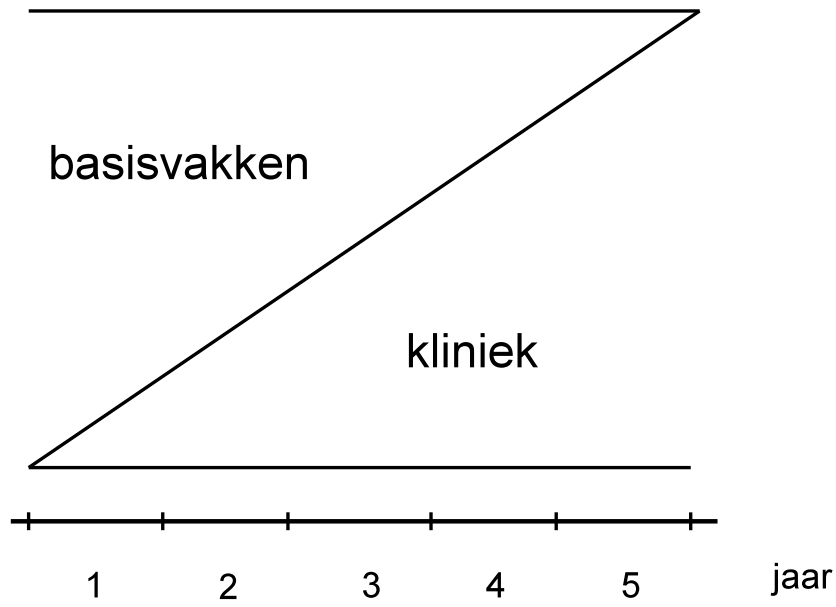

Figuur 8. Z-vormig opbouw curruculum

De eerste vijf jaar van het curriculum kent een Z-vormige structuur. In de eerste drie jaar ruim aandacht voor de basisvakken met inbreng van de kliniek, daarna draait de verhouding om. Op papier ziet het PGOgeneeskunde curriculum er ideaal uit, maar de werkelijkheid is helaas weerbarstiger. Dit komt echter niet tot uitdrukking in de waardering van onze studenten voor het genoten onderwijs. Al jaren prijkt het Maastrichtse medische onderwijs bovenaan de lijst van de 8 medische faculteiten. 
Maar een hoge mate van populariteit onder de studenten wil nog niet garanderen dat de kwaliteit hoog is. Wat is er niet in orde of liever waar is er nog ruimte voor verbetering? Om met Figuur 8 te beginnen: het implementeren van deze Z-vormige structuur is vrijwel mislukt. Wel heeft de kliniek ruim toegang gekregen tot de eerste drie jaar, maar van een substantiële bijdrage van de basisvakken aan jaar 4 en 5 is helaas geen sprake. Maar er is meer. Vanaf het begin van de MFM in 1974 zijn een aantal weeffouten aanwezig of er kort daarna ingeslopen, die er toe hebben geleid dat het onderwijs niet optimaal is. Om te voorkomen dat deze rede verzandt in een deerniswekkende litanie, wordt beperkt tot een viertal voorbeelden.

1. De student (of onderwijsgroep) formuleert zelf zijn leerdoelen en vergaart zelf relevante informatie nodig om de aangereikte problemen op te lossen.

2. Het PGO onderwijs dient docent-onafhankelijk te zijn; de vakdocent blijft onzichtbaar om het leerproces van de student niet te verstoren. De tutor, een stafmedewerker, in de onderwijsgroep is meer procesbewaker dan docent. Inhoudsdeskundigheid is geen vereiste.

Wat het eerste voorbeeld betreft: zou het niet aanbevelenswaardig zijn om eerst het juiste gereedschap te verwerven voordat het toegepast gaat worden in complexe medische problemen? Dit verwerven van gereedschap, waar ik uiteraard gedegen kennis mee bedoel, kan kleinschalig gerealiseerd worden in door deskundigen begeleide werkgroepen of in socratische lessen waarin de interactie tussen vakdocent en student gegarandeerd is. Als de geauthoriseerde kennis door de studenten is eigen gemaakt, worden zij vervolgens in staat gesteld deze kennis toe te passen in het oplossen van complexe medische problemen, het liefst onder begeleiding van ter zake kundige stafmedewerkers om te zorgen voor tijdige en adequate feed-back en de discussie op niveau te laten plaatsvinden. Het zal duidelijk zijn dat de combinatie van de eerste twee weeffouten het probleem versterkt. Door de feitelijke onzichtbaarheid van de vakdocent kan niet worden voorkomen dat het leerproces in de onderwijsgroep diepgang verliest en aan intensiteit inboet. De derde weeffout is het huidige toetssysteem.

3. Het toetssysteem: de bloktoets en voortgangstoets toetsen feitenkennis.

Het toetssysteem is in mijn ogen, ondanks de goed bedoelde inzet van velen, eveneens niet geslaagd te noemen. De wijze van toetsing, aan het einde van een blok middels een bloktoets en vier keer per jaar door middel 
van de voortgangstoets, heeft maar weinig met het PGO karakter van doen. Zowel in de bloktoets als de voortgangstoets wordt vooral feitenkennis op punitieve wijze getoetst, en is er vrijwel geen aandacht voor het vermogen van de student om deze kennis in te zetten voor het oplossen van complexe medische problemen of het construeren van de juiste fysiologische en pathofysiologische concepten. Daarnaast wordt het de student toegestaan om binnen een toets het gebrek aan kennis binnen één vakgebied te compenseren met dat van één of meerdere andere vakgebieden. Door dit toe te staan wordt in de hand gewerkt dat de student hiaten in zijn kennis laat voortbestaan en wordt geen gebruik gemaakt van het positieve feedback effect dat van een goed opgezette toetsing uitgaat.

4. De klassieke opzet van de co-schappen.

Van meet af aan werden de co-schappen in Maastricht volgens het klassieke onderwijsmodel aangeboden met dezelfde beperkte keuze aan medische disciplines, zoals al sinds het begin van de vorige eeuw gebruikelijk was in de rest van Nederland. Hoewel de co-assistent veelal lange dagen aanwezig is op de stageplaats, is de onderwijs-dichtheid vaak beperkt en is van enige PGO-benadering nauwelijks sprake, enkele goede uitzonderingen daargelaten. Ook, zoals al eerder vermeld is bij de Z-vormige structuur van het curriculum, hebben de basisvakken zeer beperkte toegang gekregen tot deze fase van het curriculum, zodat kansen onbenut blijven om samen met klinici interessante medische problemen te identificeren en als uitgangspunt te gebruiken voor het verkrijgen van een beter begrip van de pathofysiologische mechanismen van het onderliggende ziektebeeld. Ook zal door een intensievere inbreng van de basisvakken tijdens de co-schappen vleugels gegeven kunnen worden aan een beter begrip van de gewenste therapie en het verdere verloop van de ziekte. Dit type onderwijs vraagt om wekelijkse terugkomdagen die volledig aan kleinschalig probleemgestuurd onderwijs worden besteed en waaraan ondermeer de Fysiologie een belangrijke bijdrage levert.

Naast meer diepgang, kan er ook meer ruimte gecreëerd worden voor verbreding van het onderwijs. Hierbij doel ik op academische vorming binnen het medisch curriculum: academische vorming die geacht wordt te leiden tot een academische attitude van de basisarts.

Parallel aan het verschijnen van het Raamplan Artsopleiding 2009 (13), waarin voor het eerst expliciet academische vorming aan de orde wordt gesteld, hebben Jos op 't Root, Raymond Leclercq en ondergetekende 
aandacht besteed aan het belang van academische vorming in het geneeskunde curriculum en zijn tot een uitgebreid voorstel gekomen. Om een programmatische uitwerking te faciliteren, is een schema opgesteld dat in het bijgevoegde Venn-diagram (Figuur 9) is weergegeven (14) Hierin worden drie aspecten van academische vorming onderscheiden: het domein van de Doener, de Denker en de Docent: de drie D's. De Doener heeft betrekking op de arts die opgeleid is tot wetenschapper, een persoon die de fundamentele regels van wetenschappelijk onderzoek kent en in staat is zelfstandig wetenschappelijk onderzoek uit te voeren. Hij/zij kan een wetenschappelijke vraagstelling formuleren, een onderzoeksprotocol opstellen, onderzoek verrichten en verkregen gegevens na een juiste statistische bewerking analyseren en correct interpreteren. Als hij/zij niet persoonlijk bij onderzoek betrokken is, dan begrijpt de basisarts de eisen die aan goed wetenschappelijk onderzoek gesteld worden en is in staat om wetenschappelijke artikelen te lezen en een gefundeerd oordeel te vellen over de kwaliteit ervan. Ook is hij/zij in staat om de onderzoeksresultaten te implementeren in de dagelijkse praktijk na weging en schifting.

De Denker is geschoold in wetenschapsfilosofie en kennisleer, kan omgaan met vragen wat wetenschap inhoudt, wat de aard is van paradigmawisselingen, begrijpt dat kennis niet absoluut is, zodat ogenschijnlijk vaststaande kennis herzien of aangepast kan worden door nieuwe wetenschappelijke inzichten. Ook de geschiedenis van de wetenschap in het algemeen en van de geneeskunde in het bijzonder zal door hem/haar bestudeerd worden om te begrijpen wat de oorsprong is van onze huidige kennis.

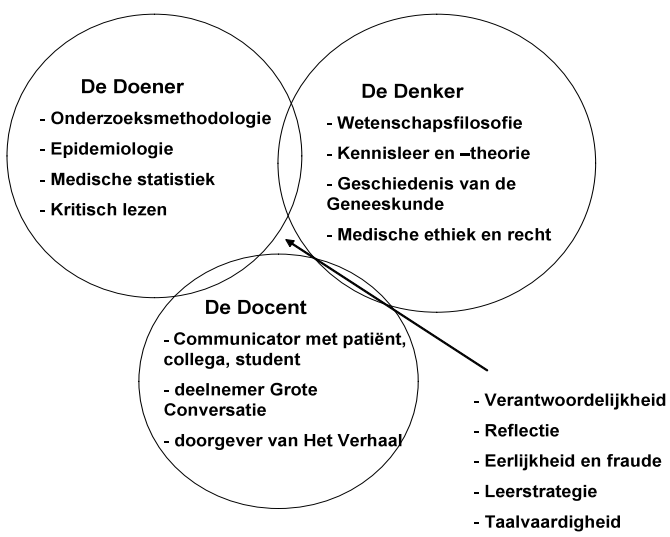

Figuur 9. Venn-diagram met academische vorming (14) 
Gedegen inzicht in Medische ethiek en gezondheidsrecht behoren eveneens tot het domein van de Denker. De basisarts als Docent beschikt over de vaardigheid om in duidelijke bewoordingen het verhaal te vertellen. Dit geldt voor de communicatie met de patiënt, met collega's en met studenten; hij/zij zal in staat zijn lastige concepten helder over het voetlicht te brengen en deel te nemen aan wat Kronman de Grote Conversatie noemt: een reeds eeuwen geleden ingezette discours over de belangrijke vragen van het leven, waar filosofen, wetenschappers en kunstenaars aan deelnemen en waar nieuwe generaties voortdurend een bijdrage aan leveren, een conversatie waarvan artsen niet worden uitgesloten.

In het gebied waar de drie domeinen elkaar overlappen komen aspecten naar voren die mede van groot belang zijn voor het verkrijgen van een academische attitude: het nemen van verantwoordelijkheid ten aanzien van de patiënt, van zichzelf als wetenschapper en hulpverlener en zijn/haar taak ten behoeve van de maatschappij. Ookwordt hiertoe gerekend het vermogen tot reflectie, ondermeer op eigen functioneren als wetenschappelijk onderzoeker en toepasser van wetenschappelijk verkregen kennis, en aspecten als eerlijkheid, vrij zijn van vooringenomenheid, het weerstand bieden tegen plagiaat en het onderkennen en uitbannen van fraude en bedrog. Dat aandacht voor het laatste geen overbodige luxe is blijkt uit een onlangs verschenen rapport van Julie Taitsman, werkzaam als jurist voor de Amerikaanse overheid, die inschat dat in Amerika de schade door fraude en bedrog binnen de medische professie ongeveer 60 miljard dollar op jaarbasis bedraagt (15). Voor Nederland zijn geen gegevens voorhanden, maar het vermoeden is dat ook hier de schade niet is te verwarlozen. Verder zijn van belang het ontwikkelen van persoonlijke leerstrategieën (Geneeskunde is nooit af, education permanente is dan ook een vereiste) en een hoge mate van taalvaardigheid, niet alleen in de landstaal maar ook in het wetenschappelijk Engels, de lingua franca van de hedendaagse medische wetenschap.

Academische vorming staat en valt bij een active participatie van zowel de vakdocent als de student. De ideale vakdocent zal zelf over een academische attitude beschikken omdat hij/zij, hoe dan ook, een rolmodel is in de basisartsopleiding. Academische vorming zal niet bij elke student een warm onthaal krijgen, maar medische studenten de mogelijkheid onthouden om zich academisch te vormen is geen acceptabel alternatief. Intrinsieke motivatie is evenwel een voorwaarde die tot uitdrukking gebracht wordt in de voor mij rethorische vraag: Wie zou niet bij een dergelijke wereld willen horen, een wereld waar een brede wetenschappelijke, maatschappelijke en culturele vorming geboden wordt?(16) 
Waar ik nu voor pleit is zowel meer diepgang als verbreding van het medisch onderwijs in Maastricht, een streven dat zich uitstekend laat combineren met een rationeel, minder fundamentalistisch, PGO systeem. De vraag kan gesteld worden of daarvoor binnen het curriculum ruimte en geld is. Tot nu toe laat elke onderwijsevaluatie zien dat in Maastricht de medische student gemiddeld 20 tot 25 uur per week studeert, terwijl een normale werkweek in Nederland toch op zijn minst 38 uur bedraagt. Gebrek aan ruimte of studietijd kan geen belemmering zijn voor implementatie. Geld laat zich vertalen in onderwijsuren van ter zake kundige stafmedewerkers. Omdat uitbreiding van de totale onderwijsformatie geen optie lijkt te zijn, zal gestreefd dienen te worden naar herrangschikking van onderwijstaken: minder managment, minder evaluatie, minder studentbegeleiding, maar meer vakinhoudelijk onderwijs.

\section{Maatschappelijke dienstverlening}

Overeenstemming bestaat dat Onderwijs en Onderzoek twee belangrijke pijlers zijn van het universitaire bedrijf. Over de inhoud van de derde pijler, Maatschappelijke dienstverlening, bestaat minder duidelijkheid. Wanneer het internet wordt geraadpleegd dan blijken vooral Vlaamse universiteiten expliciete aandacht te besteden aan Maatschappelijke dienstverlening. Maar in officiële documenten van de zijde van de Nederlandse regering, zoals de MUB (Modernisering Universitaire Bestuursorganisatie), wordt niet of nauwelijks aandacht besteed aan deze derde pijler. Toch is het de moeite waard om bij dit onderwerp stil te staan. Ik zou willen stellen dat het meest belangrijke dat de Unversiteit de Maatschappij kan bieden het verzorgen en aanbieden is van onderwijs op academisch niveau en het verrichten van grensverleggend wetenschappelijk onderzoek. Wat het eerste betreft: het academische niveau kan niet genoeg benadrukt worden, omdat anders de scheidslijnen tussen universitair en $\mathrm{HBO}$ onderwijs zullen vervagen. Een complexe maatschappij als de onze heeft geen mogelijkheid zich verder te ontwikkelen zonder een continue instroom van hoogopgeleide jongeren. Goed onderwijs is arbeidsintensief en duur: de maatschappij zal daar fors in dienen te investeren; van het laatste schijnen de huidige politici en beleidsmakers helaas niet overtuigd te zijn.

Dezelfde maatschappij is ook gediend met de aanwezigheid van centra waar top-onderzoek verricht wordt. Centra, waar onderzoekers, gedreven door nieuwsgierigheid, de grenzen van onze kennis opzoeken en verleggen; een 
dergelijk centrum is bij uitstek de universiteit. Ook universitair onderzoek is duur en vraagt om een grote investeringen, of te wel een ruime financiële bijdrage van de maatschappij. Momenteel wordt in Nederland ongeveer $€ 330$,- per hoofd van de bevolking aan Onderzoek\&Ontwikkeling op de gezamenlijke hoger onderwijsinstituten (universiteiten, HBO en Universitaire Medische Centra) besteed (17). Op EU niveau bevindt Nederland zich met dit bedrag in de hogere regionen. Een belangrijke vraag nu is of de maatschappij om een tegenprestatie mag vragen als zij het universitaire onderzoek financiert? Het antwoord is ja, maar wel dient helder gemaakt te worden waar deze tegenprestatie uit bestaat. Het zal duidelijk zijn dat in mijn visie wetenschappelijk onderzoek gedreven wordt door nieuwsgierigheid en grensverleggend dient te zijn. Hierdoor verkregen kennis is van grote en onschatbare waarde, het latijnse woord valere is hier goed op zijn plaats, omdat deze kennis bijdraagt aan de culturele ontwikkeling van onze samenleving. Het is interessant te constateren dat de laatste decennia universitaire bestuurders ook regelmatig het woord "waarde" gebruiken, en wel in de context dat universitaire kennis gevaloriseerd dient te worden. Ingegeven door het zakelijk nutsdenken, dient wetenschappelijke kennis een economische waarde te krijgen, plat gezegd, geld op te brengen, het liefst voor de universiteit waar het onderzoek wordt uitgevoerd. In het verlengde hiervan ligt het verrichten van contractresearch door universitaire onderzoekers omdat deze een bron van inkomsten is die de universiteit en de onderzoeksscholen niet mogen negeren. Recente ontwikkelingen zoals het ter beschikking stellen van een deel van de aardgasbaten aan consortia, waarin zowel het bedrijfsleven als de universiteiten participeren, completeren het door mij geschetste beeld. Een beeld dat nog versterkt wordt door suggesties dat de universiteit een belangrijke factor dient te zijn in 's lands economisch herstel en ontwikkeling. Het zal duidelijk zijn dat ik, vanuit mijn comfortabele positie als emeritus, deze ontwikkeling met argusogen gade sla. Ook wortels, die universitaire onderzoekers voorgehouden krijgen ondermeer in beloftes van het Netherlands Genomics Initiative (18) onder de schreeuwerige aanhef "Start tomorrow's company today", dat "Worth up to $€ 250.000$,- it offers superb prospects for those looking to exploit their fundamental research commercially by starting up a new business", vragen om een uiterst kritische opstelling.

Als de tegenprestatie niet behoort te bestaan uit een onmiddellijk zichtbaar economisch nut, waaruit dan wel? Wetenschappelijk onderzoek binnen universitaire centra is nauw verbonden met de opleiding en scholing van promovendi en post-docs. Het merendeel van deze jonge onderzoekers 
zullen hun verdere carrière buiten de muren van de universiteit zoeken. Juist deze hoogopgeleiden vertegenwoordigen een niet te onderschatten factor in het onderhouden en stimuleren van onze kenniseconomie. Een vereiste is dan wel dat het bedrijfsleven investeert in zijn eigen onderzoeks- en ontwikkelingspotentieel, zodat de aan de universiteit opgeleide onderzoekers daar emplooi kunnen vinden. Met het laatste is het evenwel treurig gesteld in Nederland. Volgens richtlijnen van de EU worden de lidstaten geacht in de nabije toekomst 3\% van hun bruto binnenlands product (bbp) aan Onderzoek\&Ontwikkeling te besteden. In 2009 bedroeg dit getal voor Nederland 1.8\%, waarbij ons land ver achterblijft bij ondermeer Finland, Zweden, Frankrijk, Duitsland en Denemarken (17). Schrijnender wordt het nog als blijkt dat de private sector, in casu het bedrijfsleven, in Nederland slechts $47 \%$ van deze $1.8 \%$ bbp voor zijn rekening neemt, en daarmee ver achterblijft bij het merendeel van de ons omringende EU landen. De verwachting dat onderzoek binnen de universiteit het tekortschieten van het bedrijfsleven kan compenseren is een illusie en als beleidsdoelstelling ongewenst.

Is dit het enige dat te melden is over de Maatschappelijke dienstverlening? In een in 1987 opgesteld advies van de Onderwijsraad (19) wordt gesteld dat de universiteiten verantwoordelijkheid dragen voor het voortbestaan van de cultuur en het doorgeven van cultureel erfgoed aan de volgende generaties. Daar valt niet af af te dingen en wordt door mij ten volle onderschreven, maar daar dient het zeker niet bij te blijven. Een belangrijke dienst die de universiteit de maatschappij ook kan leveren is dat zij "de luis in haar pels" is. Een universiteit die meewerkt aan het opleiden van jongeren die weerstand kunnen bieden tegen de wanen van de dag en maatschappelijke ontwikkelingen kritisch blijven volgen. Universiteiten als broedplaats van iconoclasten die maatschappelijke dogma's, of deze nu van politieke, culturele of religieuze aard zijn, weten te identificeren en te ontmaskeren, zal niet automatisch aanleiding geven tot een liefde- en begripsvolle verstandhouding tussen universiteit en matschappij, die bovendien ook nog geacht wordt voor de financiële middelen te zorgen om deze instituties in stand te houden. 


\section{Fysiologie als metafoor}

Met enige aarzeling ga ik expliciet in op de titel die ik mijn afscheidsrede heb meegegeven, omdat ik de betekenis van de Fysiologie als discipline, zowel voor het medisch onderwijs alsook voor wetenschappelijk onderzoek, impliciet in mijn lezing heb trachten te verwerken. De titel "Fysiologie als metafoor" is primair niet overdrachtelijk bedoeld, hoewel er wel degelijk grond voor deze interpretatie gevonden kan worden. De souplesse van

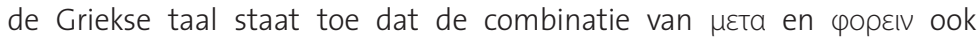
letterlijk genomen kan worden als "ergens naar toe brengen" of "in het midden plaatsen". In die zin staat de Fysiologie als discipline in het midden van de Levenswetenschappen. Deze positie is geenszins gebaseerd op een automatisme. De Fysiologie heeft deze plaats verkregen door in het verleden te onderkennen dat vakgebieden als fysica, schei- en wiskunde voor het fysiologisch onderzoek van essentieel belang zijn voor het aanleveren van meettechnieken en theoretische modellen. Om dezelfde redenen zal de Fysiologie zich niet af kunnen wenden van recente ontwikkelingen binnen vakgebieden als Genetica, Moleculaire Biologie en Systeem Biologie. Maar eveneens voert de Fysiologie ons naar integratief leren denken en het conceptueel benaderen van complexe problemen, ook buiten het eigenlijke domein van de Fysiologie en andere disciplines binnen de levenswetenschappen. Voorbeelden hiervan zijn ondermeer terug te vinden in het visionaire betoog van Lovelock in zijn in 1979 verschenen boek Gaia (20). 


\section{Dankwoord}

Het probleem van een dankwoord is dat velen zich genoemd hadden willen horen, maar dat de spreker daar vanwege de beperkte tijd geen mogelijkheid toe zag. Daarom wil ik collectief iedereen van de vakgroep Fysiologie bedanken voor de plezierige en vruchtbare samenwerking tijdens de afgelopen 35 jaar. Dit geldt ook voor de vele promovendi die ik heb mogen begeleiden, evenals postdocs en senior onderzoekers. Ook alle medewerkers van CARIM en de vele vakgroepen daarbuiten waar ik of op onderzoeks- of op onderwijsgebied mee heb samengewerkt. Toch kan ik het niet laten om enkele personen bij naam te noemen. Te beginnen met Henk van der Molen, mijn promotor aan de Erasmus Universiteit Rotterdam. Hij heeft mij als geen ander geleerd dat goed onderzoek staat en valt met betrouwbare meettechnieken, tot in den treure uitgetest en gevalideerd. Zonder een betrouwbare meettechniek wordt door wetenschappelijk onderzoek voornamelijk ruis gegenereerd. Ten tweede Vic Bonke, één van de fysiologen van het eerste uur in Maastricht, die mij heeft laten zien dat het geven van onderwijs in de Fysiologie een verrijkende ervaring is. Ten slotte Rob Reneman, die mij in staat gesteld heeft om Fysioloog te worden en mij bovenal heeft getoond dat wetenschap een bij uitstek boeiend en intellectueel uitdagend spel is.

Als laatste mijn naaste familie: Annelies, Marc en Sabine, Marleen en Sjoerd, en Reinier, en niet te vergeten mijn kleinkinderen Gwendolijn, Charlotte en Thieme. Jullie aanwezigheid in mijn leven doet zelfs de Fysiologie verbleken.

Ik heb gezegd. 


\section{Referenties}

1. G.J. van der Vusse, J.F.C. Glatz, H. Stam, R.S. Reneman. Physiol. Rev. 1992; 72: 881-940

2. G.J. van der Vusse. Drug Metab. Pharmacokinet. 2009; 24: 300-307

3. F. Schaap, B. Binas, H. Danneberg, G.J. van der Vusse, J.F.C. Glatz. Circ. Res. 1999; 85: 329-337

4. J.E. de Vries, M.M. Vork, T.H.M. Roemen, Y.F. de Jong, J.P.M. Cleutjens, G.J. van der Vusse, M. van Bilsen. J. Lipid Res. 1997; 38: 1384-1394

5. M. van Bilsen, F.A. van Nieuwenhoven. Expert Opin. Ther. Targets. 2010; 14 1029-1045

6. C. de Duve. Singularities. 2005. Cambridge Univ. Press

7. G.H. Vijgen, N.D. Bouvy, G.J. Teule, B. Brans, P. Schrauwen, W.D. van Marken Lichtenbelt. PLoS One; 2011; 6:e17247

8. P. Kemecsei, Z. Miklos, T. Biro, R. Marincsak, B.I. Toth, E. Komlodi-Pasztor, E. Barnucz, E. Mirk, G.J. van der Vusse, L. Ligeti, T. Ivanics. Mol. Cell. Biochem. 2010; 342, 251-260

9. De Bijbel. 2004. Querido-Jongbloed

10. Binas. 1998. Wolters-Noordhoff, Groningen

11. R. Roijers, N. Debernardi, J.P. Cleutjens, L.J. Schurgers, P.H. Mutsaers, G.J. van der Vusse. Am. J. Pathol. 2011; 178: 2879-2887

12. B. Haveman. Oh, gelukkige eenzaamheid. 1977. Erven Thomas Rap.

13. Raamplan Artsopleiding 2009. 2009. NFU.

14. G.J. van der Vusse, R.M.F.M. Leclercq, J.M.H. op 't Root, A.C. Nieuwenhuijzen Kruseman. Tijdschrift Medisch Onderwijs; 2011: in druk.

15. J. Taitsman. New Eng. J. Med. 2011; 464: 102-103

16. H. Procee. Bij die wereld wil ik horen. 2004. Boom, Amsterdam

17. CBS publikatie “ICT, Kennis en Economie 2011”; via http://www.cbs.nl

18. Netherlands Genomics Initiative. 2011; via htpp://www.preseedgrant.nl

19. Advies van de Onderwijsraad van 13 november 1987 m.b.t. hoger onderwijs en onderzoeksplan (HOOP); via http://www.onderwijserfgoed.nl

20. J.E. Lovelock Gaia. 1979. Oxford Univ. Press 


\section{Colophon}

Design \& print: Océ Business Services, Maastricht

Lettertype The Sans Light op Océ Top Colour 100 gr papier

Afbeelding omslag: Raymond Leclercq, aquarel (augustus 2011)

ISBN: 978-905-681-376-5

NUR: 874

All rights reserved. No part of this publication may be reproduced, modified, stored in a retrieval system or made public without the prior written permission of the author or publisher. 